\title{
A Case Report on Genetic Analysis of Exon2 of Thyroid Transcription Factor 2 Gene in Congenital Hypothyroidism Patient
}

\author{
Marjia Khatun and Laila Anjuman Banu
}

\section{ABSTRACT}

\begin{abstract}
A-3-year- old Bangladeshi pediatric patient named Tasin was presented with a diagnosed case of congenital hypothyroidism ( $\mathrm{CH})$. This type of hypothyroidism may occur due to the alteration in the nucleotide sequences of the Thyroid transcription factor 2 gene. Few studies are present on the genetic basis of this disease. $\mathrm{CH}$ is common in Bangladesh, may be due to geographical variation or other causes. Therefore, this study was conducted to identify whether there was any genetic alteration in the exon 2 of Thyroid transcription factor 2 gene.
\end{abstract}

With due procedure and permission from the guardian of the pediatric patient, socio-demographic data was collected. Isolation of DNA, quantitation and qualitation of DNA was ensured, polymerase chain reaction (PCR) was performed, the amplicons that was obtained from PCR; validated visually by gel electrophoresis methods; cycle sequencing was performed by Sanger sequencing. The chromatogram data that was obtained from Sanger sequencing was analyzed and compared with the National Center for Biotechnology Information database by Basic Local Alignment Search Tool search. Sanger sequencing revealed substitution $(\mathbf{c} .1051 \mathrm{G}>\mathrm{T})$ in the Sequence Tagged Site of the exon 2 of Thyroid transcription factor 2 gene and this is new variants and not reported in National Center for Biotechnology Information database.

Keywords: Bangladeshi, Congenital Hypothyroidism, Thyroid transcription factor 2 gene, Substitution.
Submitted : February 27, 2021

Published : March 31, 2021

ISSN: $2593-8339$

DOI: $10.24018 /$ ejmed.2021.3.2.744

\section{Dr Marjia Khatun}

Department of Anatomy, Bangabandhu Sheikh Mujib Medical University, Bangladesh.

Prof Dr Laila Anjuman Banu*

Professor of Genetics and Molecular Biology, Department of Anatomy, Bangabandhu Sheikh Mujib Medical University, Bangladesh.

(e-mail: dr.lailabanu@ ${ }^{\circledR}$ gmail.com)

\section{INTRODUCTION}

The global frequency of Congenital hypothyroidism is 1 in 3000-4000 whereas a pilot study in Bangladesh reported an incidence rate of 1 in 1300 [1]. CH is defined as S. TSH level more than $20 \mathrm{mlU} / \mathrm{L}$ at less than 2 weeks of age or $\mathrm{S}$. TSH level more than $10 \mathrm{ml} / \mathrm{U}$ after 2 weeks of age [2].

\section{CASE PRESEnTATION}

The patient's name is Tasin, a 3-year-old Bangladeshi boy. $\mathrm{He}$ was diagnosed with a case of congenital hypothyroidism at two months of age. At the time of diagnosis, he was presented with jaundice, large protruding tongue, irregular bowel movement with difficulty in defecation and highly raised $\mathrm{S}$. TSH level $(50 \mathrm{ml} / \mathrm{U})$. He was born spontaneously with a term gestational age. His mother was also a hypothyroid patient. Other family member of his family could not mention any thyroid disorder. After the proper treatment, he was almost normal with slightly raised S. TSH level $(19 \mathrm{ml} / \mathrm{U})$. Then after two years he again presents with several problems such as for overweight, the delayed milestone of development with raised S. TSH level $(39 \mathrm{ml} / \mathrm{U})$ due to irregularity in treatment.

\section{Methods of GeNetic ANALYsis}

\section{A. Isolation of DNA}

With all aseptic precaution three $(3 \mathrm{ml})$ venous blood was drawn from the patient. Genomic DNA was extracted by using DNA extraction kit as per manufacturer's instructions. About $200 \mu \mathrm{l}$ blood was mixed with proteinase $\mathrm{K}$ and cell lysis buffer within the microcentrifuge tube. For yielding the extracted DNA; binding buffer, wash buffer and elution buffer were used sequentially. For extraction of DNA from the blood, the required amount of the reagents was taken as per SOP (Standard Operating Procedure). By using NanoDrop spectrophotometer, the quantity and quality of the extracted DNA was measured and checked.

\section{B. Amplification of DNA}

For amplification of the targeted region of exon2 of Thyroid transcription factor 2 gene, forward and reverse primers were designed by using Primer 3 plus software, as shown in the Table I. The desired portion of Thyroid transcription factor 2 gene was amplified by conventional PCR (polymerase chain reaction). Amplification was performed on a Biometra thermal cycler (Biometra $\mathrm{GmbH}$, Germany). The amplicons were visually confirmed by $1 \%$ agarose gel electrophoresis. PCR products were sent for Sanger sequencing. 
TABLE I: THE FORWARD* (F) AND REVERSE* (R) PRIMERS, AND RELEVANT INFORMATION

\begin{tabular}{cccccc}
\hline \multirow{2}{*}{ Primer } & Sequence & $\begin{array}{c}\text { Primer } \\
\text { position }\end{array}$ & GC \% & $\begin{array}{c}\text { Tm }\left({ }^{\circ} \mathrm{C}\right) \\
\text { Product } \\
\text { size }\end{array}$ \\
\hline $\mathrm{F}^{*}$ & 5'- ACG AGG ATC CCT TAC CAT TAC TGT -3' $^{\prime}$ - & 7104 & $45.8 \%$ & $57.2^{\circ} \mathrm{C}$ & $938 \mathrm{bp}$ \\
$\mathrm{R}^{*}$ & 5'- ACT CAT TGC ACG CTG CAT AAT -3' & 7951 & $42.9 \%$ & $55.4^{\circ} \mathrm{C}$ & 938 \\
\hline
\end{tabular}

\section{Sequencing of DNA}

The PCR products were run by using ABI-3500 Genetic Analyzer (Thermo Fisher Scientific, USA) for Sanger sequencing, for running the cycles, BigDye ${ }^{\circledR}$ Terminator v3.1 Cycle Sequencing Kit were used.

\section{Data Analysis}

The results of the sequencing run in Sanger sequencers was represented by a four-colored chromatogram. By using Chromas ${ }^{\circledR}$ software, the obtained data were analyzed. The sequences was compared with the National Centre for Biotechnology Information database by Basic Local Alignment Search Tool, as shown in the Fig. 1.

\section{E. Ethical Implication}

The diagnosed pediatric patient with $\mathrm{CH}$ was treated with due respect. Verbal and written consents was obtained from the patients' guardian that the DNA sample obtained from the blood of the pediatric patient named Tasin was used for research purpose only.

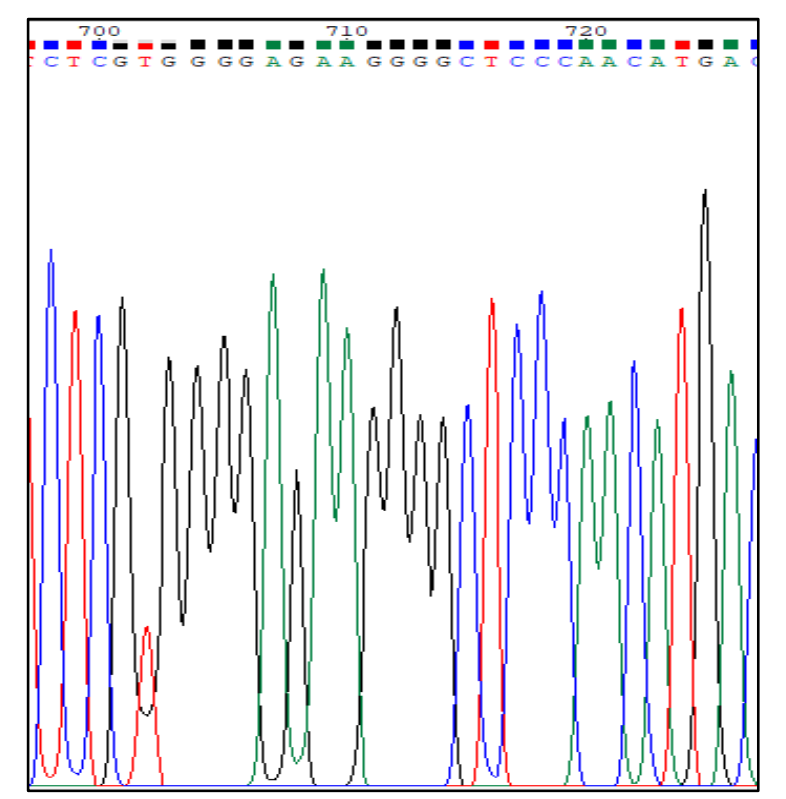

Fig. 1. In ID CH01, 'G' has been substituted by 'T' (c.1051 G>T) at nucleotide position $1051 \mathrm{bps}$.

\section{DISCUSSION}

$\mathrm{CH}$ may be defined as the elevated levels of Thyroid Stimulating Hormone (TSH) at birth [3]. Some infants with $\mathrm{CH}$ are asymptomatic at birth, even when there is complete agenesis of thyroid gland, some presents with several problems within few weeks of birth [4]. Patients with thyroidal $\mathrm{CH}$ can be divided into two types. One is less frequent form and accounts for about 10-15\% (dyshormonogenesis), Another group represents $80-85 \%$ of all cases with $\mathrm{CH}$ and comprises all different forms of disordered thyroid gland development (dysembryogenesis and dysgenesis) [5]. CH with dyshormonogenesis and goiter occurs due to the genetic alteration in one of the genes that code for synthesis of the thyroid hormone. $\mathrm{CH}$ with dysembryogenesis and dysgenesis constitutes a heterogeneous group of affections due to disturbances in the organogenesis of the thyroid gland which may leads to thyroid agenesis, athyreosis, hypoplasia and thyroid ectopy [6]. According to various data, the development and migration of embryonic thyroid gland occurs due to the interactions between several transcriptions' factors. Four of these transcription factors are, paired domain factor: paired box gene 8 , Thyroid transcription factor 1, forkhead box E1 and thyroid transcription factor 2 [7]. They play a vital role in the differentiation and growth process of normal thyroid anlage. Therefore, these genes are responsible for the occurrence of nongoitrous types of $\mathrm{CH}$. Such as, CHNG1 occurs due to the defect in the TSHR gene, CHNG2 due to the defect in PAX8 gene, CHNG5 due to defect in the Thyroid transcription factor gene 2. These Thyroid transcription factor 2 gene is a homeodomain containing transcription factors.

The genomic location of these genes is on chromosome five between the base pairs $173,232,109$ to $173,235,321$. It is a protein coding gene. This Thyroid transcription factor 2 gene has two exons and three introns. Among them, exon2 and exon-intron boundaries of exon 2 are the most common sites for genetic alteration [8]. Though in the early period of organogenesis these transcription factor gene controls both the development of heart and thyroid gland. In the later period of organogenesis, These Thyroid transcription factor 2 gene is restricted to the thyroid primordium area, genetic alteration of the Thyroid transcription factor gene2, plays a key role in the development of congenital hypothyroidism [9]. Thyroid transcription factor 2 gene have sequence Tag site (STS) from 7776 bps to 7977bps whose location and base sequence are known. It could serve as marker for genetic and physical mapping of the gene [10]. In this case report, this patient was selected for identification of genetic alteration in the exon 2 of the Thyroid transcription factor 2 gene. The Thyroid transcription factor 2 gene has two exons, one coding sequences, and one Sequence Tagged Site (STS) area. The exon 2 of Thyroid transcription factor 2 gene is $1100 \mathrm{bps}$ in length, which extends from 7104 to 8204 bps and also contain STS [8].

In this case report, the primer was designed covering the whole region of exon 2 of the Thyroid transcription factor 2 gene. On the basis of Sanger sequencing method and interpretation of chromatogram data, substitution was identified at $1051 \mathrm{bp}$ (c.1051G > T bp) which occurred in the STS area. STS sequences have a single occurrence in the genome and whose location and base sequence are known and can be uniquely amplified by the polymerase chain reaction (PCR) using a pair of primers [11].

As this substitution does not involve in amino acid alteration. And as it is present in the STS area it may be used as a probe and in chromosome mapping [11]. Several studies are present on the Thyroid transcription factor 2 gene. 
Brust et al., performed a study on $\mathrm{CH}$ patients with primary aged 3 to 19 years [12]. All the patients with $\mathrm{CH}$ presented with high TSH levels after 4 weeks of levothyroxine suspension. They observed synonymous variation (SNP rs2277923) within the Thyroid transcription factor 2 gene in the study population that did not change the amino acid.

Khatami et al. performed study on Iranian population to identify mutation among the study population. Regarding mutation detection they found two polymorphisms. A heterozygous missense mutation $(\mathrm{c} .73 \mathrm{C}>\mathrm{T})$ and transition (c.63A>G) in exon1 of the Thyroid transcription factor 2 gene have been recognized among the study population. No change was revealed in the exon2 of this Thyroid transcription factor 2 gene [9].

Dentice et al. performed study covering the entire coding sequence of the Thyroid transcription factor 2 gene. They detect three mutations (R25C, A119S, and R161P) in four patients with thyroid dysgenesis. Among them three patients had thyroid ectopy and one patient had athyreosis [13]. They recommend that the Thyroid transcription factor 2 gene is involved in the pathogenesis of $\mathrm{CH}$.

From the above mentioned discussion, many studies are present in regard to the genetic analysis of the Thyroid transcription factor 2 gene in $\mathrm{CH}$. Polymorphism was detected on the study population but no mutation was found previously. And most importantly, the previously described study did not reveal any mutation and or polymorphism in the Sequence tag site region of the exon2 of Thyroid transcription factor 2 gene.

The identified changes in the nucleotide that is found in this case report might be due to several reasons. It may be due to geographic variation. This case report for the detection of nucleotide alteration in the Thyroid transcription factor 2 gene in $\mathrm{CH}$ patient will serve the opportunity in diagnosis, prognosis and also in therapeutic purposes.

\section{REFERENCES}

[1] Begum, N, Islam, T, Hossain, SR, Bhuyan, GS, Halim, MA, Shahriar, I, Sarker, SK, Haque, S, Konika, TS, Islam, S, Rahat, A, Qadri, SK, Sultana, R, Begum, S, Sultana, S, Saha, N, Hasan, M, Hasanat, MA, Banu, H, Shekhar, HU, Chowdhury, EK, Sajib, AA, Islam, ABM, Qadri, SS, Qadri, F, Akhteruzzaman, S \& Mannor, K 2019, 'Mutation spectrum in TPO gene of Bangladeshi patients with thyroid dyshormonogenesis and analysis of the structural features and functions of TPO protein through in silico approach', Biomedical Research International, 2019, 1-18,

[2] Naik SM, Ravishankara, S, Appaji, M, Gautom, MK, Devi, NP \& Naik, SS, 'Congenital hypothyroidism: follow up of a case for 13 years,' Otolaryngology online journal.4,2,2014.

[3] Park, SM \& Chatterjee, VKK, 2005, 'Genetics of congenital hypothyroidism', Journal of Medical Genetics, 45, 5, 379-389.

[4] Maswiryati, AA \& Westra, N2003, "Congenital hypothyroidism: a case report", Pediatrica Indonesia, 43, 1-2, 2003.

[5] Szinnai, G, 'Clinical genetics of congenital hypothyroidism', Pediatric Thyroidology, vol. 26, pp. 60-78, 2014.

[6] Montanelli L \& Tonacchera M, "Genetics and phenomics of hypothyroidism and thyroid dys- and agenesis due to PAX8 and TTF1 mutations," Molecular \& Cellular Endocrinology. 322. 64-71, 2010.

[7] Narumi, S, Muroya, K, Asakura, Y, Adachi, M \& Hasegawa, T, "Transcription factor mutations and congenital hypothyroidism: Systematic genetic screening of a population-based cohort of Japanese patients," J Clin Endocrinol Metabol. 95, 1981-1985, 2010.

[8] National Center for Biotechnology Information (NCBI) 2017, Homo sapiens Annotation release 109, RefSeqGene on chromosome 5 GRCh38.

[9] Khatami M, Heidari MM, Tabesh F, Ordooei M \& Salehifar Z
"Mutation analysis of $N K X 2.5$ gene in Iranian pediatric patients with congenital hypothyroidism," J Pediatr Endocrinol Metabol. 10, 1-6, 2017.

[10] Green, ED \& Green, P, "Sequence tagged site content mapping of human chromosome: Theoretical consideration and early experience," Genome Research. 1, 77-90, (1991).

[11] Marjia, K, Chowdhury, SS, Khan, TH \& Banu, LA, "Identification of mutation in exon 2 of the NKX2.5 gene in Bangladeshi pediatric patients with congenital hypothyroidism" Europian journal of medical \& health sciences, 2, 5, 2020.

[12] Brust ES, Beltrao CB, Chammas MC, Watanabe T, Sapienza MT \& Marui S, "Absence of mutations in $P A X 8, N K X 2.5$ and TSH receptor genes in patients with thyroid dysgenesis," Arch Braz Endocrinol Metab, 56, 173-177, 2012.

[13] Dentice M, Cordeddu V, Rosica A, Ferrara AM, Santarpia L, Salvatore D, Chiovato L, Perri A, Moschini L, Fazzini C, Olivieri A, Costa P, Stoppioni V, Baserga M, De Felice M, Sorcini M, Fenzi G, Di Lauro R, Tartaglia M \& Macchia PE, "Missence mutation in the transcription factor $N K X 2.5$ : A novel molecular event in the pathogenesis of thyroid dysgenesis," J Clin Endocrinol Metabol. 91, 4, 1428-1433, 2006.

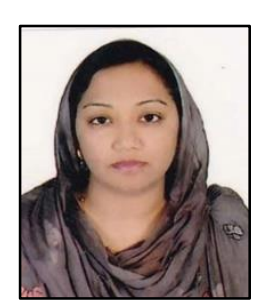

Dr. Marjia Khatun MBBS, MS in Anatomy. She completed her post-graduation (MS) in anatomy in 2020 from Bangabandhu Sheikh Mujib Medical University, Dhaka, Bangladesh. Currently she is a lecturer of the Department of Anatomy at Khulna Medical College, Khulna, Bangladesh. During the period of her post-graduation at Bangabandhu Sheikh Mujib Medical University, Dr. Marjia conducted her research on genetic basis of congenital hypothyroidism in the pediatric patients. Her main research interest includes molecular and genetic basis of medical disorders. Dr. Marjia has publications in refereed journals on the topic of BRCA1 mutation in the breast cancer patients as a co-author.

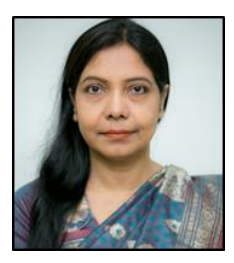

Prof. Dr. Laila Anjuman Banu

A career medical professional and teacher she is now working as Prof. Genetics and Molecular Biology in the Department of Anatomy at Bangabandhu Sheikh Mujib Medical University (BSMMU). She passed 9th Bangladesh Civil Service (BCS Health Cadre), earlier, and entered into Ministry of Health and Family Welfare, during her professional carrier she worked at several renowned medical Institute like Dhaka Medical College and Sir Salimullah medical college. She also served as the Chairman, Department of Anatomy of BSMMU from 2015 to 2018. In addition to his current responsibility, he also established a Genome Research Laboratory at BSMMU under Higher Education Quality Enhancement project (HEQEP) funded by World Bank and GOV. of Bangladesh. She has a MS degree in molecular Biology, as well as Masters of Medical Education (MMEd), Master of Philosophy (MPhil) and Bachelor MBBS Degree. She is adjunct faculty of Bangladesh College of Physicians and Surgeons (BCPS) and Bangladesh Medical Research Council (BMRC). She organized and represented numerous international meetings and international conferences related to medical professional. she is trained in latest molecular technology from as Academic Medical Center, University Amsterdam, Netherlands, UK, Singapore, Thailand, Malaysia, and India. She participated in a number of Global Good Ethical and Legal Issues of human genomics n Programmer as Senior lead researchers. She has extensive research knowledge in the human genome research and post graduate medical curriculum development in Ministry of Health and Family Welfare and Ministry of Education of Bangladesh. She has more than sixty indexed articles in International Journal and she is acting as reviewer and editor of number of International Journal. She published number of book chapters in Jaypee Medical Publishers of India. She also supervises number of these research of BSMMU.

She has more than sixty indexed articles in International Journal and she is acting as reviewer and editor of number of International Journal. She published number of book chapters in Jaypee Medical Publishers of India. She also supervises number of these research of BSMMU. 